\title{
Foliar application of selenium (Se) at heading stage induces regulation of photosynthesis, yield formation, and quality characteristics in fragrant rice
}

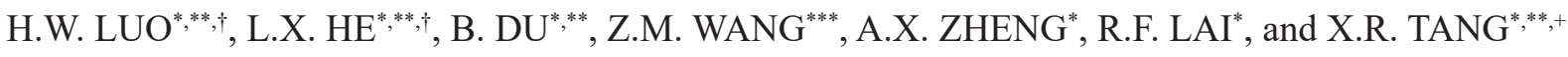 \\ Department of Crop Science and Technology, College of Agriculture, South China Agricultural University, \\ 510642 Guangzhou, China* \\ Scientific Observing and Experimental Station of Crop Cultivation in South China, Ministry of Agriculture, \\ 510642 Guangzhou, China** \\ College of Engineering, South China Agricultural University, 510642 Guangzhou, China***
}

\begin{abstract}
In order to study the effect of foliar application of sodium selenate on fragrant rice performance at the heading stage, the present study was conducted with two fragrant rice cultivars, 'Meixiangzhan-2' and 'Xiangyaxiangzhan'. At the heading stage, six concentrations of sodium selenate solution $\left(0,10,20,30,40\right.$, and $\left.50 \mu \mathrm{mol} \mathrm{L}{ }^{-1}\right)$ were sprinkled to plants. Our results showed that foliar application of sodium selenate increased chlorophyll contents in rice leaves and upregulated net photosynthetic rate at the grain-filling stage. The enhancement was observed in grain yield, seed-setting rate, and in

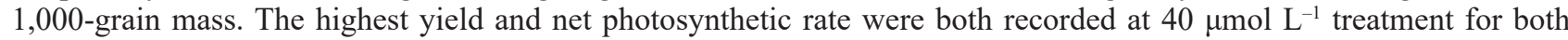
cultivars. Furthermore, foliar application of sodium selenate also improved some grain quality attributes, such as head rice rate and crude protein content. The Se concentration in fragrant rice grain also increased due to sodium selenate application. In conclusion, sodium selenate has potential to be the exogenous plant growth regulator in fragrant rice production to increase yield and quality.
\end{abstract}

Additional key words: 1,000-grain mass; aromatic rice; gas exchange; microelement; photosynthetic capacity.

\section{Introduction}

As the curiosa in rice (Oryza sativa L.), fragrant rice is desired by people because of the taste and optimal flavour and other preferred features (Ren et al. 2017). In recent years, fragrant rice is fetching premium prices in international markets and the demand is increasing around the world (Mo et al. 2016). Thus, farmers and researchers begin to pay more attention to a problem how to increase fragrant rice yield and promote a grain quality. An exogenous plant growth regulator might become an effective way to improve fragrant rice yield.

Photosynthesis is an important physiological process and significantly affects the rice growth and development. A previous study showed that about $90 \%$ of the dry matter formed during the growth and development of crops came from photosynthetic assimilates (Petridis et al. 2018). The study of Thussagunpanit et al. (2015) also showed that photosynthetic rate is one of the limiting factors in the yield formation of rice. Furthermore, the research of Wu et al. (2008) revealed that the higher light intensity could enhance photosynthetic rate and increase the dry matter accumulation and finally improve the grain yield of rice. Therefore, photosynthesis is a key part in aroma rice production to improve fragrant rice yield and ensure the yield stability.

Selenium (Se), as a trace and non-metallic element, plays an essential role in physiological activities of plants. In 1982, an investigation evidenced that Se application could alleviate the stress of crops caused by toxic elements, such as arsenic, antimony, mercury, and copper (Gotsis 1982). The research of $\mathrm{Hu}$ et al. (2014) revealed that $\mathrm{Se}$ fertilizer could significantly decrease the accumulation of cadmium and lead in rice tissues and thus alleviate the damage caused by these elements. The study of Wang et al. (2012) also showed that foliar application of Se at low concentration could activate the antioxidant system and enhance photosynthesis while the higher Se concentration could damage the photosynthetic apparatus and inhibit photosynthesis. Hence, Se might have potential to be the exogenous regulator in rice production. However, the effects of selenate application on photosynthesis, yield

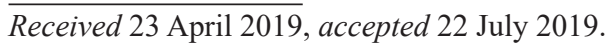

${ }^{+}$Corresponding author; phone/fax: +20-8528-0204-618, e-mail: tangxr@scau.edu.cn

Abbreviations: $C_{\mathrm{i}}-$ intercellular $\mathrm{CO}_{2}$ concentration; $E$ - transpiration rate; $g_{\mathrm{s}}-$ stomatal conductance; $P_{\mathrm{N}}-$ photosynthetic rate; WUE - water-use efficiency.

Acknowledgements: This study was supported by National Natural Science Foundation of China (31971843), the World Bank Loan Agricultural Pollution Control Project in Guangdong (0724-1510A08N3684), the Technology System of Modern Agricultural Industry in Guangdong (2017LM1098) and Student's Platform for Innovation and Entrepreneurship Training Program (201810564029).

†These authors have contributed equally to this work. 
formation and grain quality of fragrant rice were rarely studied. Therefore, in this study, we compared the rice photosynthesis, grain quality, and yield under five different concentrations of sodium selenate to explore effects of foliar application of Se on fragrant rice performance.

\section{Materials and methods}

Plant materials and growing conditions: Seeds of two fragrant rice cultivars, 'Xiangyaxiangzhan' and 'Meixiangzhan-2', widely grown aromatic rice in Guangdong Province, China, were provided by College of Agriculture, South China Agricultural University, Guangzhou, China. Before sowing, the seeds were soaked in water for $24 \mathrm{~h}$, germinated in manual climatic boxes for another $12 \mathrm{~h}$, then shade-dried, followed by sowing in polyvinyl chloride trays for nursery raising. Then, the 20 -d-old seedlings were transplanted to the fields at the planting distance of $30 \times 12 \mathrm{~cm}$. Field experiment between July and November 2017 was conducted at Experimental Research Farm, College of Agriculture, South China Agricultural University, Guangzhou, China $\left(23^{\circ} 16^{\prime} \mathrm{N}, 113^{\circ} 23^{\prime} \mathrm{E}\right.$, and $11 \mathrm{~m}$ from mean sea level). The experimental soil in Guangzhou was sandy loam containing $15.7 \%$ organic matter, $0.96 \%$ total $\mathrm{N}, 0.76 \%$ total $\mathrm{P}$, and $12.46 \%$ total $\mathrm{K}$. The experimental sites enjoyed a subtropical monsoon climate (Fig. 1).

Treatments and plant sampling: Six treatments were realized by overhead sprinkle with $0,10,20,30,40$, and $50 \mu \mathrm{mol} \mathrm{L}{ }^{-1}$ sodium selenate $\left(\mathrm{Na}_{2} \mathrm{SeO}_{4}\right.$; Shandong Xiya Chemical Co., Ltd., China) at the heading stage, marked further as $\mathrm{CK}, \mathrm{Se} 1, \mathrm{Se}$, $\mathrm{Se}$, Se4, and $\mathrm{Se} 5$, respectively. The treatments were arranged in randomized complete block design (RCBD) in triplicates with net plot size of $21 \mathrm{~m}^{2}$. Fifteen litres of corresponding liquid was applied to each plot, respectively. Fresh leaves were separated and collected from the rice plants at the grain-filling stage (after $15 \mathrm{~d}$ of the heading stage), washed with double distilled water, and stored at $-80^{\circ} \mathrm{C}$ for biochemical analysis. At

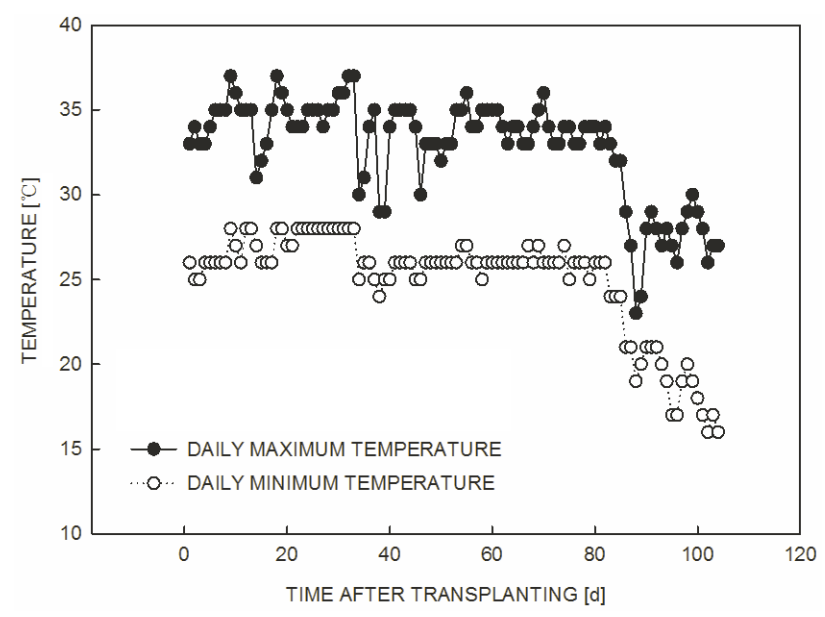

Fig. 1. Daily maximum and minimum temperatures during the experiment. maturity, the rice plants were collected from thirty hills in each plot and the sampled plants were oven-dried at $80^{\circ} \mathrm{C}$ until constant mass to record total biomass.

Photosynthetic parameters: During the grain-filling stage (after $15 \mathrm{~d}$ of heading stage), portable photosynthesis system (LI-6400, LI-COR, USA) was used to determine net photosynthetic rate $\left(P_{\mathrm{N}}\right)$, stomatal conductance $\left(g_{\mathrm{s}}\right)$, intercellular $\mathrm{CO}_{2}$ concentration $\left(C_{\mathrm{i}}\right)$, transpiration rate $(E)$, and water-use efficiency (WUE) at 09:00-10:30 h according to Kong et al. (2017) with the following adjustments: PAR at leaf surface was 1,100 and 1,200 $\mu$ mol(photon) $\mathrm{m}^{-2} \mathrm{~s}^{-1}$, ambient $\mathrm{CO}_{2}$ concentration was 385 and $400 \mu \mathrm{mol}$ $\mathrm{mol}^{-1}$, air temperature was $31.5 \pm 0.5^{\circ} \mathrm{C}$ with $60-80 \%$ relative air humidity. SPAD meter SPAD-502 (Konica Minolta, Japan) was used for precise, rapid, and nondestructive estimation of leaf chlorophyll (Chl) content.

Chl and soluble protein content: The estimation of photosynthetic pigment and soluble protein were done using the methods described by He et al. (2019). The fresh leaf samples $(0.1 \mathrm{~g})$ were extracted with $95 \%$ alcohol and the absorbance was read at $665,649,652$, and $470 \mathrm{~nm}$ (UV-VIS spectrophotometer UV-2550, Shimadzu, Japan). The soluble protein content was measured by using Brilliant Blue G-250 (Shanghai Aladdin Biochemical Technology Co., Ltd., China), the absorbance was read at $595 \mathrm{~nm}$ and expressed as $\mu \mathrm{g} \mathrm{g}^{-1}(\mathrm{FM})$.

Se content in grains, leaves, and stems: For sample preparation, the mature grain and leaf from rice plants were dried in a fume hood at $50^{\circ} \mathrm{C}$. Then, brans were separated and the seeds were ground into powder. Total Se content in polished grain was determined by using atomic absorption spectrophotometer (Z2300, HITACHI, Japan) with hydride generator (HFS-3, HITACHI, Japan). Before the estimation, 0.1-g samples were digested with $1.5 \mathrm{ml}$ of concentrated $\mathrm{HNO}_{3}$ and $0.5 \mathrm{ml} 30 \% \mathrm{H}_{2} \mathrm{O}_{2}$ in a digestive stove at $180^{\circ} \mathrm{C}$ for $1.5 \mathrm{~h}$. The digested product was reconstituted to $10 \mathrm{ml}$ with Milli-Q water and autosampled for total Se determination (Wang et al. 2013).

Yield and yield-related traits: At the maturity stage, the rice grains were harvested from five units of sampling area $\left(1.75 \mathrm{~m}^{2}\right)$ in each plot and then threshed by machine. The harvested grains were sun-dried and weighted in order to determinate the grain yield. Twenty hills of rice from different locations in each plot were randomly collected for the estimation of effective panicles number per hill. Then, six hills of representative plants were taken for estimation of the yield-related traits including seed-setting rate and 1,000-grain mass.

Grain quality attributes: After sun-drying, grains were stored at room temperature for at least a month to determine grain quality components. Brown rice rate was estimated using a rice huller (Jiangsu, China) and milled rice and head rice recovery rates were calculated by using a Jingmi testing rice grader (Zhejiang, China). Grains with chalkiness and chalkiness degree were estimated by 
using an $S D E-A$ light box (Guangzhou, China) while an Infratec-1241 grain analyzer (FOSS-TECATOR) was used to determine the grain amylose and protein contents.

Statistical analysis: Data were analyzed on Statistix 8.1 (Analytical Software, Tallahassee, FL, USA), while differences between means were separated by using least significant difference (LSD) test at 5\% probability level. Graphical representation was conducted via SigmaPlot 14.0 (Systat Software Inc., California, USA).

\section{Results}

Chl content: Foliar applications of sodium selenate significantly increased $\mathrm{Chl}$ contents (Fig. 2). Compared to CK, Se treatments increased the total Chl content by $4.2-15.0 \%$. The trend of $\mathrm{Chl} a$ content was recorded as: $\mathrm{Se} 4>\mathrm{Se} 5=$ Se3 $>$ Se2 $>$ Se1 $>$ CK for both 'Meixiangzhan-2' and 'Xiangyaxiangzhan'. Similar trends were also observed in Chl $b$ and carotenoid content.

Soluble protein content: As shown in Fig. 3, compared to $\mathrm{CK}, \mathrm{Se} 3$ and $\mathrm{Se} 4$ treatments significantly increased the soluble protein content in leaves of both cultivars. For 'Meixiangzhan-2', compared with CK, Se3 and Se4 treatments increased soluble protein in leaves by 7.1 and $13.0 \%$, respectively. For 'Xiangyaxiangzhan', 15.2 and $8.1 \%$ higher soluble protein contents were recorded under $\mathrm{Se} 3$ and $\mathrm{Se} 4$ compared with CK.
Photosynthesis and SPAD values: Foliar application of sodium selenate at the heading stage significantly affected photosynthesis during the grain-filling stage (Fig. 4). Compared with $\mathrm{CK}$, all Se treatments (except Se1 in 'Meixiangzhan-2') enhanced $P_{\mathrm{N}}$ significantly. In $\mathrm{Se} 2$, $\mathrm{Se} 3, \mathrm{Se} 4$, and $\mathrm{Se} 5,13.6,11.8,24.5$, and $11.7 \%$ higher $P_{\mathrm{N}}$ was recorded for 'Meixiangzhan-2', respectively. For 'Xiangyaxiangzhan', 12.7, 18.6, 27.7, 38.0, and 31.7\% higher $P_{\mathrm{N}}$ in $\mathrm{Se} 1, \mathrm{Se} 2, \mathrm{Se} 3, \mathrm{Se} 4$, and $\mathrm{Se} 5$ were found,

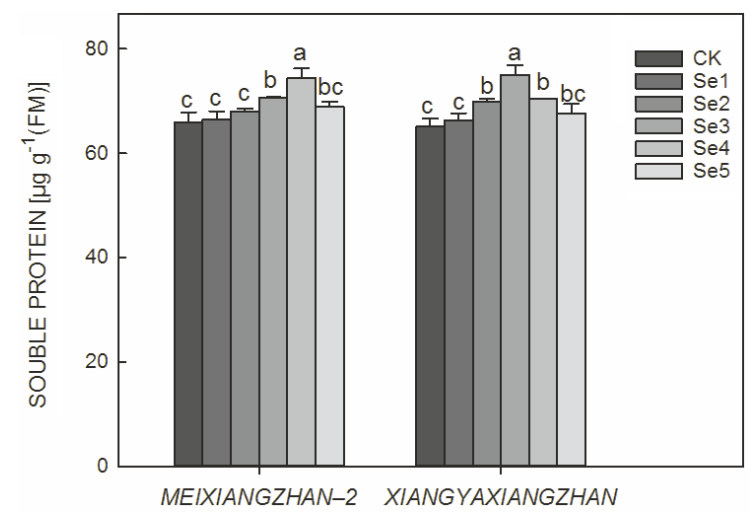

Fig. 3. Effect of sodium selenate on soluble protein in leaves of two fragrant rice cultivars. Bars represent SE of three replicates. Means sharing the same letter do not differ significantly at $P \leq 0.05$ according to least significant difference (LSD) test for both cultivars. CK, $\mathrm{Se} 1, \mathrm{Se} 2, \mathrm{Se} 3, \mathrm{Se} 4$, and $\mathrm{Se} 5-0,10,20,30$, 40 , and $50 \mu \mathrm{mol} \mathrm{L}^{-1}$ sodium selenate, respectively.

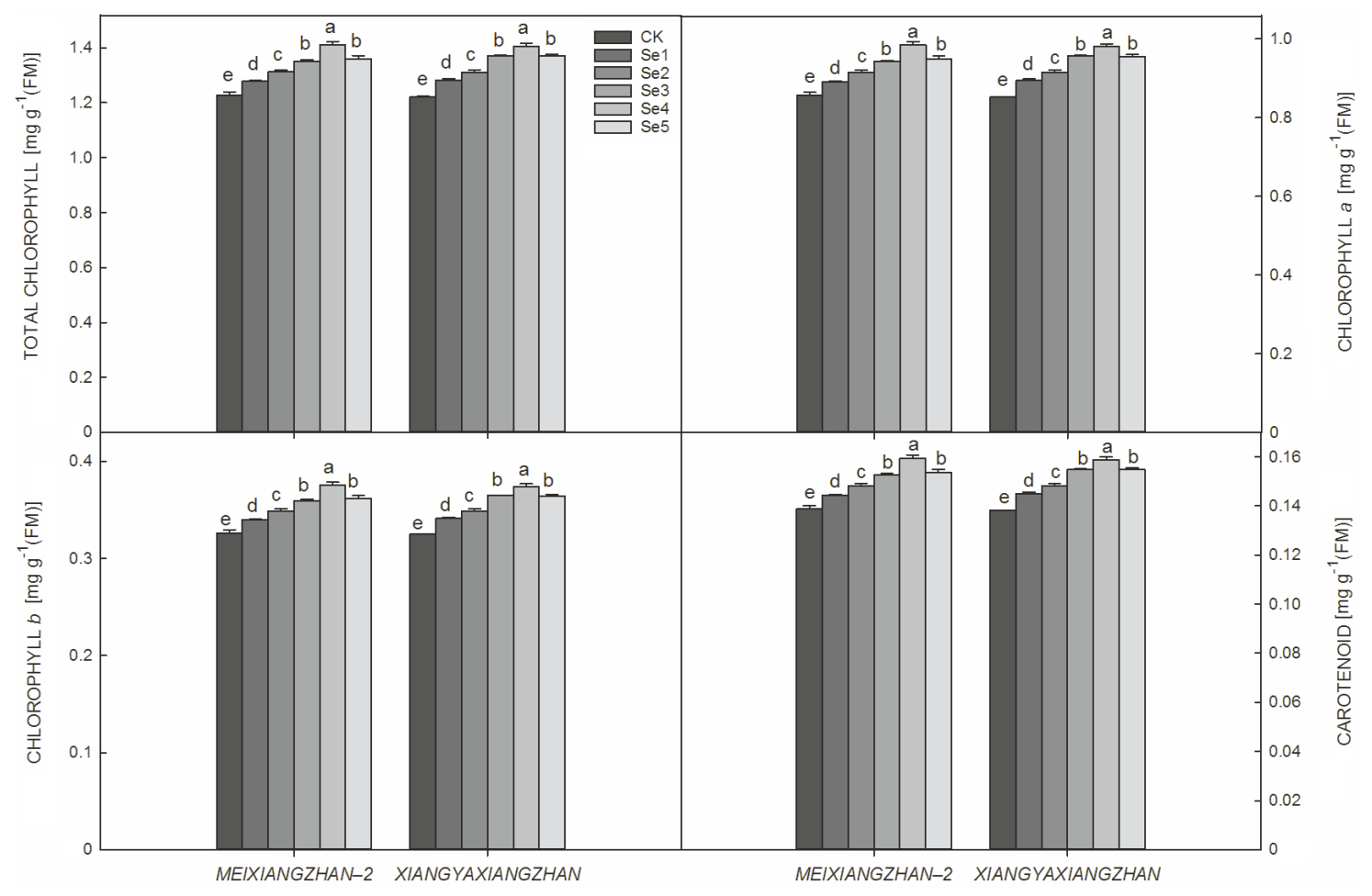

Fig. 2. Effect of sodium selenate on chlorophyll contents of two fragrant rice cultivars. Bars represent SE of three replicates. Means sharing the same letter do not differ significantly at $P \leq 0.05$ according to least significant difference (LSD) test for both cultivars. $\mathrm{CK}, \mathrm{Se} 1, \mathrm{Se} 2, \mathrm{Se} 3, \mathrm{Se} 4$, and $\mathrm{Se} 5-0,10,20,30,40$, and $50 \mu \mathrm{mol} \mathrm{L}{ }^{-1}$ sodium selenate, respectively. 




Fig. 4. Effect of sodium selenate on net photosynthesis, gas exchange, and SPAD values of two fragrant rice cultivars. Bars represent SE of three replicates. Means sharing the same letter do not differ significantly at $P \leq 0.05$ according to least significant difference (LSD) test for both cultivars. CK, Se1, Se2, Se3, Se4, and Se 5-0, 10, 20, 30, 40, and $50 \mu \mathrm{mol} \mathrm{L}^{-1}$ sodium selenate, respectively.

respectively. The highest $g_{\mathrm{s}}$ was recorded in $\mathrm{Se} 4$ treatment for 'Meixiangzhan-2'. For 'Xiangyaxiangzhan', all Se treatments remarkably increased $g_{s}$. Compared with $\mathrm{CK}$, values for $C_{\mathrm{i}}$ remained at a lower level under $\mathrm{Se} 2, \mathrm{Se} 3$, $\mathrm{Se} 4$, and Se5 treatments. Furthermore, compared with $\mathrm{CK}, \mathrm{Se} 2, \mathrm{Se} 3, \mathrm{Se} 4$, and Se5 significantly increased SPAD values, while the highest value was recorded at $\mathrm{Se} 4$ for both cultivars. In addition, there was no significant difference in $E$ and WUE between different treatments.

Dry matter accumulation at maturity: Foliar application of sodium selenate at the heading stage significantly affected the dry matter accumulation in fragrant rice (Fig. 5). For 'Meixiangzhan-2', dry matter masses higher by $7.3,9.3,13.4,13.7$, and $12.0 \%$ were recorded in Se1, $\mathrm{Se} 2, \mathrm{Se} 3, \mathrm{Se} 4$, and $\mathrm{Se} 5$, respectively, compared with $\mathrm{CK}$ at maturity. For 'Xiangyaxiangzhan', dry matter masses higher by $2.6,8.7,11.7,11.9$, and $10.7 \%$ compared with $\mathrm{CK}$ were observed in $\mathrm{Se} 1, \mathrm{Se} 2, \mathrm{Se} 3, \mathrm{Se} 4$, and $\mathrm{Se} 5$, respectively.

Se content: As shown in Fig. 6, foliar application of sodium selenate significantly increased the Se content in fragrant rice. Compared with CK, 1.58-, 1.11-, 1.36-, 1.50-, and 1.45-fold higher Se contents in grain were recorded in $\mathrm{Se} 1$, $\mathrm{Se} 2, \mathrm{Se} 3, \mathrm{Se} 4$, and Se5, respectively, for 'Meixiangzhan-2'. For 'Xiangyaxiangzhan', Se1, Se2, Se3, Se4, and Se5 treatments increased the Se content by 36.9, 80.3, 79.3, 117.3 , and $113.5 \%$, respectively. The similar trend was recorded in the Se content of leaves. Moreover, compared with $\mathrm{CK}, \mathrm{Se} 4$ and $\mathrm{Se} 5$ also significantly increased the $\mathrm{Se}$ content in stems.

Yield and related attributes: Different Se treatments 


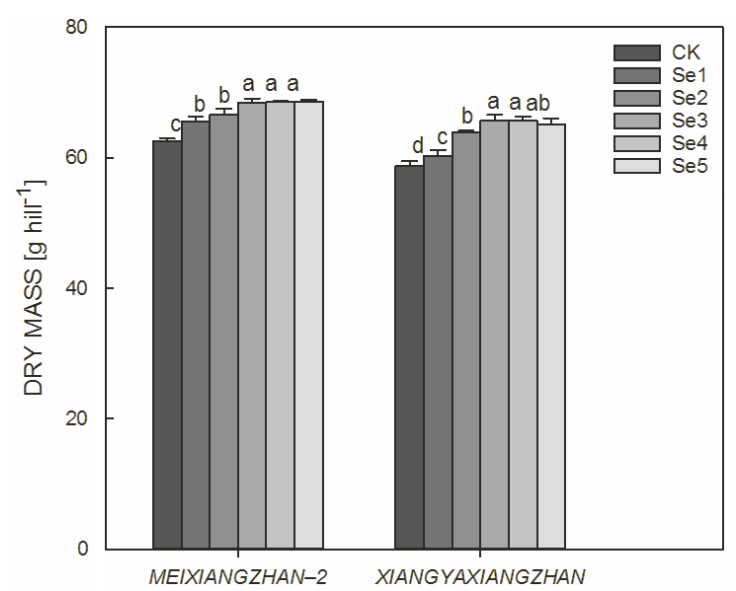

Fig. 5. Effect of sodium selenate on dry matter accumulation of two fragrant rice cultivars. Bars represent SE of three replicates. Means sharing the same letter do not differ significantly at $P \leq 0.05$ according to least significant difference (LSD) test for both cultivars. CK, Se1, Se2, Se3, Se4, and Se5 - 0, 10, 20, 30, 40 , and $50 \mu \mathrm{mol} \mathrm{L}{ }^{-1}$ sodium selenate, respectively.

affected rice yield and related attributes significantly (Table 1). For 'Meixiangzhan-2', the seed-setting rates of $\mathrm{Se} 2, \mathrm{Se} 3, \mathrm{Se} 4$, and $\mathrm{Se} 5$ were significantly higher than that of CK, i.e., by $83.2,81.9,85.7$, and $82.4 \%$, respectively. Higher 1,000-grain masses were also observed in $\mathrm{Se} 2$ and Se4 than that of CK, 20.34 and 20.99 g, respectively. Furthermore, the highest yield was recorded in the Se4 treatment. For 'Xiangyaxiangzhan', compared with $\mathrm{CK}$, $\mathrm{Se} 2, \mathrm{Se} 3$, and $\mathrm{Se} 4$ treatments remarkably improved the seed-setting rate, while the 1,000-grain masses of $\mathrm{Se} 2$, $\mathrm{Se} 3, \mathrm{Se} 4$, and Se5 were significantly higher than that of CK, i.e., 20.09, 20.11, 21.11, and 20.53 g, respectively. Furthermore, Se2, Se3, Se4, and Se5 showed the higher yields than that of CK. In addition, there was no significant difference between different treatments in panicle number per hill and grain number per panicle for both cultivars.

Grain quality: As shown in Table 2, foliar application of sodium selenate improved grain quality of fragrant rice in terms of brown rice rate, milk rice rate, head rice rate, crude protein, and chalky rice rate. For 'Meixiangzhan-2', both $\mathrm{Se} 3$ and $\mathrm{Se} 4$ treatments significantly increased brown rice rate, milk rice rate, head rice rate, and crude protein content in grains compared with CK. Se3 also significantly decreased chalky rice rate and chalkiness. For 'Xiangyaxiangzhan', higher brown rice rates, milk rice rates, and head rice rates were recorded in Se4 and Se5 compared with CK, while all Se applications significantly increased crude protein content in grains.

\section{Discussion}

The photosynthesis of fragrant rice is affected by several agronomic and external climatic factors. Present study focused on the effect of exogenous sodium selenate application at the heading stage on photosynthesis, yield formation, and grain quality in fragrant rice. It

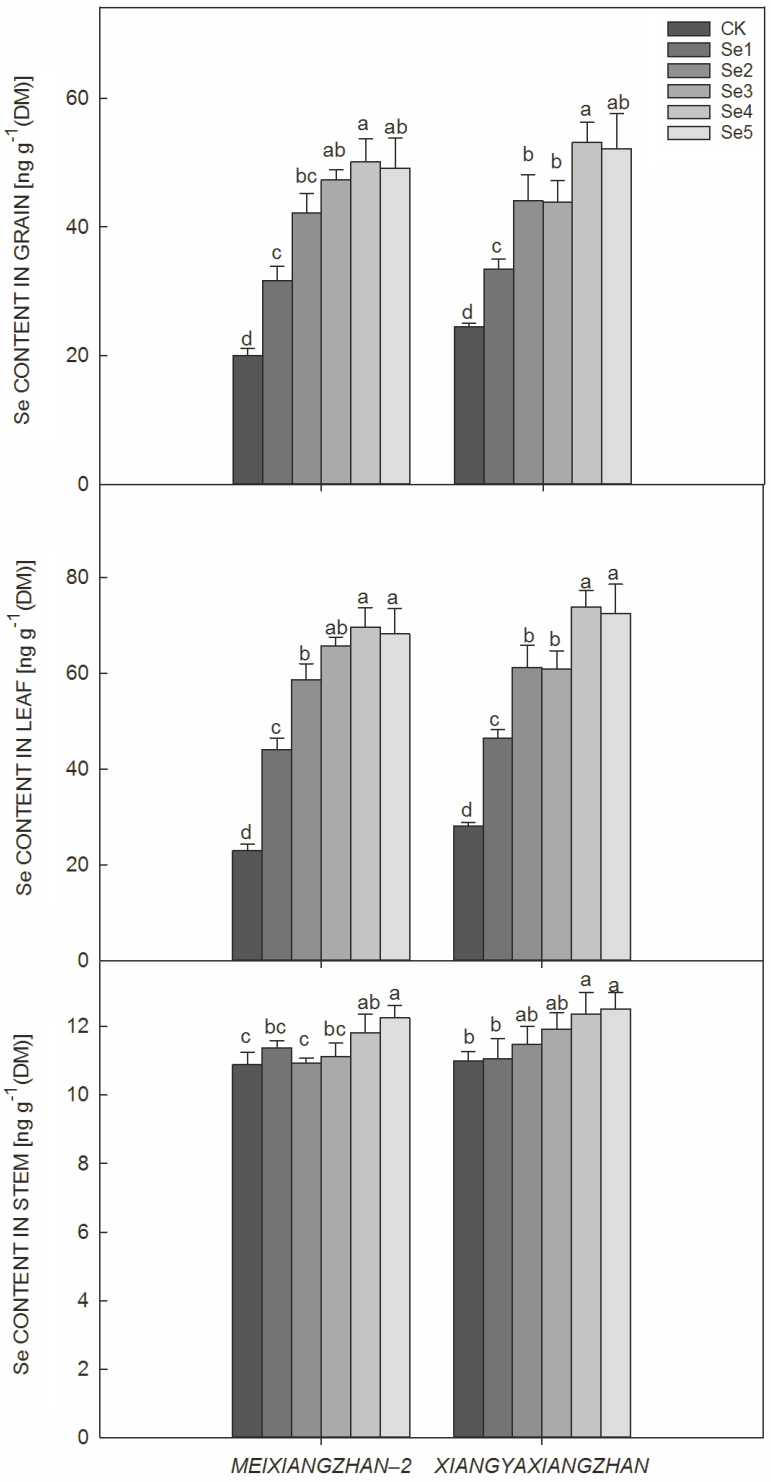

Fig. 6. Effect of sodium selenate on Se content in grains, leaves, and stems of two fragrant rice cultivars. Bars represent SE of three replicates. Means sharing the same letter do not differ significantly at $P \leq 0.05$ according to least significant difference (LSD) test for both cultivars. CK, Se1, Se2, Se3, Se4, and Se5 - 0, 10, 20, 30, 40, and $50 \mu \mathrm{mol} \mathrm{L} \mathrm{L}^{-1}$ sodium selenate, respectively.

was found that foliar application of sodium selenate significantly increased the $P_{\mathrm{N}}$ at the grain-filling stage for both 'Meixiangzhan-2' and 'Xiangyaxiangzhan'. Compared with control, Se applications increased the $P_{\mathrm{N}}$ by $2.2-24.6 \%$ and $12.7-37.6 \%$ for 'Meixiangzhan-2' and 'Xiangyaxiangzhan', respectively, while the highest $P_{\mathrm{N}}$ were both recorded in the $\mathrm{Se} 4$ treatment. The improvement was attributed to the increment in $g_{\mathrm{s}}$, photosynthetic pigments, and soluble proteins. Compared with $\mathrm{CK}$, foliar application of sodium selenate remarkably increased the $g_{s}$, Chl content, and soluble protein content, which corroborated with the previous reports of He et al. (2019) 
Table 1. Effect of sodium selenate on rice yield and related attributes of two fragrant rice cultivars. Values sharing the same letter within a column do not differ significantly at $P \leq 0.05$ according to least significant difference (LSD) test for both cultivars. *,** - significant at $p<0.05$ and $p<0.01$, respectively, ns - insignificant. CK, Se1, Se2, Se3, Se4, and Se5 - 0, 10, 20, 30, 40, and $50 \mu$ mol L $\mathrm{L}^{-1}$ sodium selenate, respectively.

\begin{tabular}{|c|c|c|c|c|c|c|}
\hline Cultivar & Treatment & $\begin{array}{l}\text { Panicle number } \\
\text { per hill }\end{array}$ & $\begin{array}{l}\text { Grain number } \\
\text { per panicle }\end{array}$ & $\begin{array}{l}\text { Seed-setting } \\
\text { rate }[\%]\end{array}$ & $\begin{array}{l}1,000 \text {-grain } \\
\text { mass [g] }\end{array}$ & Yield $\left[\mathrm{t} \mathrm{ha}^{-1}\right]$ \\
\hline \multirow[t]{6}{*}{ Meixiangzhan-2 } & $\mathrm{CK}$ & $21.47^{\mathrm{a}}$ & $136.31^{\mathrm{a}}$ & $78.08^{\mathrm{d}}$ & $19.66^{\mathrm{c}}$ & $4.46^{\mathrm{b}}$ \\
\hline & $\mathrm{Se} 1$ & $21.52^{\mathrm{a}}$ & $134.39^{\mathrm{a}}$ & $79.68^{\mathrm{cd}}$ & $19.85^{\mathrm{bc}}$ & $4.45^{\mathrm{b}}$ \\
\hline & $\mathrm{Se} 2$ & $22.85^{\mathrm{a}}$ & $137.98^{\mathrm{a}}$ & $83.15^{\mathrm{ab}}$ & $20.34^{\mathrm{b}}$ & $4.46^{\mathrm{b}}$ \\
\hline & $\mathrm{Se} 3$ & $21.64^{\mathrm{a}}$ & $136.39^{\mathrm{a}}$ & $81.94^{\mathrm{bc}}$ & $20.27^{\mathrm{bc}}$ & $4.47^{\mathrm{b}}$ \\
\hline & $\mathrm{Se} 4$ & $20.99^{\mathrm{a}}$ & $136.52^{\mathrm{a}}$ & $85.67^{\mathrm{a}}$ & $20.99^{\mathrm{a}}$ & $4.63^{\mathrm{a}}$ \\
\hline & $\mathrm{Se} 5$ & $21.65^{\mathrm{a}}$ & $137.69^{\mathrm{a}}$ & $82.37^{\mathrm{bc}}$ & $19.97^{\mathrm{bc}}$ & $4.42^{\mathrm{b}}$ \\
\hline \multirow[t]{6}{*}{ Xiangyaxiangzhan } & CK & $19.51^{\mathrm{a}}$ & $116.67^{\mathrm{a}}$ & $79.34^{\mathrm{d}}$ & $19.34^{\mathrm{d}}$ & $3.95^{\mathrm{c}}$ \\
\hline & $\mathrm{Se} 1$ & $19.44^{\mathrm{a}}$ & $113.89^{\mathrm{a}}$ & $80.48^{\mathrm{cd}}$ & $19.68^{\mathrm{cd}}$ & $4.14^{\mathrm{bc}}$ \\
\hline & $\mathrm{Se} 2$ & $19.04^{\mathrm{a}}$ & $117.96^{\mathrm{a}}$ & $82.64^{\mathrm{bc}}$ & $20.09^{\mathrm{bc}}$ & $4.24^{\mathrm{b}}$ \\
\hline & $\mathrm{Se} 3$ & $18.86^{\mathrm{a}}$ & $115.69^{\mathrm{a}}$ & $84.39^{\mathrm{ab}}$ & $20.11^{\mathrm{bc}}$ & $4.18^{\mathrm{b}}$ \\
\hline & $\mathrm{Se} 4$ & $19.01^{\mathrm{a}}$ & $117.85^{\mathrm{a}}$ & $86.19^{\mathrm{a}}$ & $21.11^{\mathrm{a}}$ & $4.50^{\mathrm{a}}$ \\
\hline & $\mathrm{Se} 5$ & $19.32^{\mathrm{a}}$ & $116.42^{\mathrm{a}}$ & $81.80^{\mathrm{bcd}}$ & $20.53^{b}$ & $4.30^{\mathrm{b}}$ \\
\hline \multicolumn{7}{|l|}{ Analysis of variance } \\
\hline Cultivar (C) & & $*$ & $* *$ & ns & $\mathrm{ns}$ & $*$ \\
\hline Selenium (Se) & & ns & ns & $* *$ & $* *$ & $* *$ \\
\hline $\mathrm{Se} \times \mathrm{C}$ & & ns & ns & ns & ns & $*$ \\
\hline
\end{tabular}

Table 2. Effect of sodium selenate on grain quality attributes of two fragrant rice cultivars. Values sharing the same letter within a column do not differ significantly at $P \leq 0.05$ according to least significant difference (LSD) test for both cultivars. *, ${ }^{* *}-$ significant at $p<0.05$ and $p<0.01$, respectively, ns - insignificant. CK, Se1, Se2, Se3, Se4, and Se5 - 0, 10, 20, 30, 40, and $50 \mu$ mol L $\mathrm{L}^{-1}$ sodium selenate, respectively.

\begin{tabular}{|c|c|c|c|c|c|c|c|c|c|}
\hline Cultivar & Treatment & $\begin{array}{l}\text { Brown rice } \\
\text { rate }[\%]\end{array}$ & $\begin{array}{l}\text { Milled rice } \\
\text { rate [\%] }\end{array}$ & $\begin{array}{l}\text { Head rice } \\
\text { rate }[\%]\end{array}$ & $\begin{array}{l}\text { Crude protein } \\
\text { content }[\%]\end{array}$ & $\begin{array}{l}\text { Amylose } \\
\text { content [\%] }\end{array}$ & Akali & $\begin{array}{l}\text { Chalky rice } \\
\text { rate }[\%]\end{array}$ & $\begin{array}{l}\text { Chalkiness } \\
{[\%]}\end{array}$ \\
\hline \multirow[t]{6}{*}{ Meixiangzhan-2 } & $\mathrm{CK}$ & $69.52^{\mathrm{b}}$ & $66.16^{\mathrm{b}}$ & $48.76^{\mathrm{c}}$ & $8.33^{\mathrm{d}}$ & $17.27^{\mathrm{a}}$ & $6.33^{\mathrm{a}}$ & $9.69^{\mathrm{a}}$ & $2.73^{\mathrm{a}}$ \\
\hline & $\mathrm{Se} 1$ & $78.18^{\mathrm{ab}}$ & $68.72^{\mathrm{ab}}$ & $55.99^{\mathrm{b}}$ & $8.42^{\mathrm{c}}$ & $17.91^{\mathrm{a}}$ & $6.41^{\mathrm{a}}$ & $6.07^{\mathrm{bc}}$ & $2.14^{\mathrm{a}}$ \\
\hline & $\mathrm{Se} 2$ & $77.30^{\mathrm{ab}}$ & $70.46^{\mathrm{a}}$ & $53.39^{\mathrm{b}}$ & $8.45^{\mathrm{b}}$ & $17.41^{\mathrm{a}}$ & $6.07^{\mathrm{a}}$ & $5.93^{b c}$ & $2.01^{\mathrm{ab}}$ \\
\hline & $\mathrm{Se} 3$ & $83.09^{\mathrm{a}}$ & $69.54^{\mathrm{a}}$ & $62.62^{\mathrm{a}}$ & $8.51^{\mathrm{a}}$ & $17.38^{\mathrm{a}}$ & $6.15^{\mathrm{a}}$ & $4.10^{c}$ & $1.03^{\mathrm{b}}$ \\
\hline & $\mathrm{Se} 4$ & $81.48^{\mathrm{a}}$ & $71.73^{\mathrm{a}}$ & $61.06^{\mathrm{a}}$ & $8.52^{\mathrm{a}}$ & $17.94^{\mathrm{a}}$ & $6.37^{\mathrm{a}}$ & $7.27^{\mathrm{abc}}$ & $2.15^{\mathrm{a}}$ \\
\hline & $\mathrm{Se} 5$ & $76.25^{\mathrm{ab}}$ & $70.02^{\mathrm{ab}}$ & $50.32^{\mathrm{cb}}$ & $8.50^{\mathrm{a}}$ & $17.26^{\mathrm{a}}$ & $6.43^{\mathrm{a}}$ & $8.06^{\mathrm{ab}}$ & $2.18^{\mathrm{a}}$ \\
\hline \multirow[t]{6}{*}{ Xiangyaxiangzhan } & $\mathrm{CK}$ & $80.06^{\mathrm{b}}$ & $59.90^{\mathrm{b}}$ & $57.64^{\mathrm{b}}$ & $7.84^{\mathrm{d}}$ & $18.74^{\mathrm{a}}$ & $6.77^{\mathrm{a}}$ & $2.24^{\mathrm{ab}}$ & $2.47^{\mathrm{abc}}$ \\
\hline & $\mathrm{Se} 1$ & $81.27^{\mathrm{b}}$ & $60.93^{\mathrm{b}}$ & $56.09^{\mathrm{b}}$ & $7.90^{\mathrm{c}}$ & $18.31^{\mathrm{a}}$ & $6.77^{\mathrm{a}}$ & $2.14^{\mathrm{b}}$ & $2.15^{\mathrm{bc}}$ \\
\hline & $\mathrm{Se} 2$ & $83.53^{\mathrm{b}}$ & $62.21^{\mathrm{b}}$ & $58.40^{\mathrm{b}}$ & $7.97^{\mathrm{b}}$ & $18.92^{\mathrm{a}}$ & $6.71^{\mathrm{a}}$ & $2.25^{\mathrm{ab}}$ & $1.91^{\mathrm{c}}$ \\
\hline & $\mathrm{Se} 3$ & $87.83 \mathrm{a}$ & $63.63^{\mathrm{ab}}$ & $57.88^{\mathrm{b}}$ & $8.00^{\mathrm{ab}}$ & $18.73^{\mathrm{a}}$ & $6.76^{\mathrm{a}}$ & $2.73^{\mathrm{ab}}$ & $2.51^{\mathrm{ab}}$ \\
\hline & $\mathrm{Se} 4$ & $89.20^{\mathrm{a}}$ & $66.51^{\mathrm{a}}$ & $61.38^{\mathrm{a}}$ & $8.03^{\mathrm{a}}$ & $18.22^{\mathrm{a}}$ & $6.63^{\mathrm{a}}$ & $2.54^{\mathrm{ab}}$ & $2.59^{\mathrm{ab}}$ \\
\hline & $\mathrm{Se} 5$ & $87.49^{\mathrm{a}}$ & $66.18^{\mathrm{a}}$ & $61.32^{\mathrm{a}}$ & $7.99^{\mathrm{ab}}$ & $18.02^{\mathrm{a}}$ & $6.78^{\mathrm{a}}$ & $3.08^{\mathrm{a}}$ & $2.82^{\mathrm{a}}$ \\
\hline \multicolumn{10}{|l|}{ Analysis of variance } \\
\hline \multicolumn{2}{|l|}{ Cultivar (C) } & $*$ & $*$ & ns & $* *$ & $*$ & $*$ & $* *$ & $\mathrm{~ns}$ \\
\hline \multicolumn{2}{|l|}{ Selenium (Se) } & $*$ & $\mathrm{~ns}$ & $\mathrm{~ns}$ & $* *$ & ns & $\mathrm{ns}$ & $*$ & $\mathrm{~ns}$ \\
\hline \multicolumn{2}{|l|}{$\mathrm{Se} \times \mathrm{C}$} & $\mathrm{ns}$ & ns & $\mathrm{ns}$ & $\mathrm{ns}$ & $\mathrm{ns}$ & $\mathrm{ns}$ & $*$ & $* *$ \\
\hline
\end{tabular}

who demonstrated that spraying appropriate concentration of sodium selenate solution at rupturing stage can increase $\mathrm{Chl}$ content of rice leaves. Chl is the pigment for plant photosynthesis and the detergent-soluble protein forms of stored $\mathrm{N}$ might be the main nitrogen sources for main- taining photosynthesis (Liu et al. 2018). The biosynthesis of $\mathrm{Chl}$ is a complicated phenomenon which involves many elements such as $\mathrm{Fe}, \mathrm{Mn}, \mathrm{Cu}$, and $\mathrm{Zn}$ (Wang and Grimm 2015). Therefore, the increment in Chl content is probably because the Se application promoted the absorption of 
mineral elements related to Chl biosynthesis (Põldma et al. 2011, Dong et al. 2013). On the other hand, previous studies also showed that appropriate selenium application could promote net photosynthetic rate of plants by reducing stomatal resistance, increasing stomatal conductance, and stomatal $\mathrm{CO}_{2}$ flux (Feng et al. 2015, Haghighi et al. 2016).

As far as fragrant rice yield was concerned, the response of 'Meixiangzhan-2' and 'Xiangyaxiangzhan' to sodium selenate application was different. For 'Meixiangzhan-2', only the Se4 treatment significantly increased the grain yield, whilst for 'Xiangyaxiangzhan', all Se treatments except Sel remarkably increased the grain yield. The difference might be due to the different sensitivity of two fragrant rice varieties to selenium. The results are in agreement with the study of Terry et al. (2000) who demonstrated that the physiological response to Se varies considerably among plants because some plant species growing on splendiferous soils are tolerant and could accumulate abundant Se, but most plants are Se non-accumulators and Se-sensitive. The increment in fragrant rice yield due to sodium selenate application could be explained by the improvement in seed-setting rate and 1,000-grain mass. Compared with $\mathrm{CK}$, foliar application of sodium selenate increased the seed-setting rate and grain mass for both fragrant rice cultivars and it might occur because the Se treatment enhanced the photosynthesis during the grain-filling stage. The study of Huang et al. (2015) also revealed that at least $90 \%$ organic matter of rice plant was translated and accumulated by $\mathrm{CO}_{2}$ assimilation. Current study agreed with the study of Kong et al. (2017) which indicated that the photosynthetic rate at grain-filling stage is one of the important factors affecting the yield of aromatic rice. Our result was also consistent with the study of Lai et al. (2019) who indicated that exogenous Se applications could increase the rice yield by regulating the photosynthesis.

Rice quality is accessed by a few characteristics, such as milling, appearance, cooking, eating, and nutrient qualities (Luo et al. 2018). Present study manifested some attributes of grain quality including milling, appearance, and nutrient quality were significantly influenced by Se applications. The results depicted that foliar application of sodium selenate not only increased the head rice rate and crude protein content in fragrant rice grain, but also decreased chalk rice rate. The improvements in fragrant rice quality could be explained by the enhanced net photosynthetic rate during the grain-filling stage. Previous study revealed that there was a strong correlation between photosynthesis during grain-filling stage and grain quality, and early study also evidenced that photosynthesis was a determining factor to grain quality of rice (Chaturvedi et al. 2017). Furthermore, present study showed that Se applications could significantly increase the Se content in fragrant rice grain. As an essential element to humans, Se sufficiency or supplementation has antiviral effects and reduces the risk of autoimmune thyroid disease. Hence, foliar application of sodium selenate at heading stage was beneficial to the cultivation of selenium-rich rice in fragrant rice production.
Conclusion: Foliar application of sodium selenate at the heading stage affected the grain yield and some quality characteristics of fragrant rice, while the best effects were recorded in $\mathrm{Se} 4$ treatment for both cultivars. Significant increases were observed in chlorophyll content, net photosynthetic rate, and stomatal conductance at the grainfilling stage. Furthermore, foliar application of sodium selenate could increase seed-setting rate and grain mass. In order to reveal the mechanism of selenium effect on the fragrant rice photosynthesis, much work should be done at molecular level.

\section{References}

Chaturvedi A.K., Bahuguna R.N., Pal M. et al.: Elevated $\mathrm{CO}_{2}$ and heat stress interactions affect grain yield, quality and mineral nutrient composition in rice under field conditions. Field Crop. Res. 206: 149-157, 2017.

Dong J.Z., Wang Y., Wang S.H. et al.: Selenium increases chlorogenic acid, chlorophyll and carotenoids of Lycium chinense leaves. - J. Sci. Food Agr. 93: 310-315, 2013.

Feng T., Chen S.S., Gao D.Q. et al:: Selenium improves photosynthesis and protects photosystem II in pear (Pyrus bretschneideri), grape (Vitis vinifera), and peach (Prunus persica). - Photosynthetica 53: 609-612, 2015.

Gotsis O.: Combined effects of selenium/mercury and selenium/ copper on the cell population of the alga Dunaliella minuta. Mar. Biol. 71: 217-222, 1982.

Haghighi M., Sheibanirad A., Pessarakli M.: Effects of selenium as a beneficial element on growth and photosynthetic attributes of greenhouse cucumber. - J. Plant Nutr. 39: 1493$1498,2016$.

He L.X., Zheng A.X., Du B. et al.: Low-concentration sodium selenate applications improve oxidation resistance of fillingstage rice. - Appl. Ecol. Env. Res. 17: 989-998, 2019.

Hu Y., Norton G.J., Duan G. et al.: Effect of selenium fertilization on the accumulation of cadmium and lead in rice plants. Plant Soil 384: 131-140, 2014.

Huang L., Dai L., Wang L. et al.: Genetic dissection for chlorophyll content of the top three leaves during grain filling in rice (Oryza sativa L.). - J. Plant Growth Regul. 34: 381-391, 2015.

Kong L., AshrafU., Cheng S. et al.: Short-term water management at early filling stage improves early-season rice performance under high temperature stress in South China. - Eur. J. Agron. 90: 117-126, 2017.

Lai R.F., Zhang T.T., Gao Y.H. et al:: The effect of EDTA-Se with different concentrations on photosynthesis of fragrant rice (Oryza sativa L.). - Appl. Ecol. Env. Res. 17: 3293-3303, 2019.

Liu T., Ren T., White P.J. et al.: Storage nitrogen co-ordinates leaf expansion and photosynthetic capacity in winter oilseed rape. - J. Exp. Bot. 69: 2995-3007, 2018.

Luo H.W., Wang Z.M., Chen Y.Y. et al.: The effects of different temperatures on the biosynthesis of grain protein in rice at filling stage. - Appl. Ecol. Env. Res. 16: 8017-8027, 2018.

Mo Z., Huang J., Xiao D. et al.: Supplementation of 2-AP, Zn and La improves 2-acetyl-1-pyrroline concentrations in detached aromatic rice panicles in vitro. - PLoS ONE 11: e149523, 2016.

Petridis A., van der Kaay J., Chrysanthou E. et al.: Photosynthetic limitation as a factor influencing yield in highbush blueberries (Vaccinium corymbosum) grown in a northern European environment. - J. Exp. Bot. 69: 3069-3080, 2018. 
Põldma P., Tõnutare T., Viitak A. et al.: Effect of selenium treatment on mineral nutrition, bulb size, and antioxidant properties of garlic (Allium sativum L.). - J. Agr. Food Chem. 59: 5498-5503, 2011.

Ren Y., Ashraf U., He L.X. et al.: Irrigation and nitrogen management practices affect grain yield and 2-acetyl-1-pyrroline content in aromatic rice. - Appl. Ecol. Env. Res. 15: 14471460, 2017.

Terry N., Zayed A.M., de Souza M.P., Tarun A.S.: Selenium in higher plants. - Annu. Rev. Plant Phys. 51: 401-432, 2000.

Thussagunpanit J., Jutamanee K., Kaveeta L. et al.: Comparative effects of brassinosteroid and brassinosteroid mimic on improving photosynthesis, lipid peroxidation, and rice seed set under heat stress. - J. Plant Growth Regul. 34: 320-331,
2015.

Wang P., Grimm B.: Organization of chlorophyll biosynthesis and insertion of chlorophyll into the chlorophyll-binding proteins in chloroplasts. - Photosynth. Res. 126: 189-202, 2015.

Wang Y.D., Wang X., Wong Y.S.: Proteomics analysis reveals multiple regulatory mechanisms in response to selenium in rice. - J. Proteomics 75: 1849-1866, 2012.

Wang Y.D., Wang X., Wong Y.S.: Generation of seleniumenriched rice with enhanced grain yield, selenium content and bioavailability through fertilisation with selenate. - Food Chem. 141: 2385-2393, 2013.

Wu W.G., Zhang H.C., Qian Y.F. et al.: Analysis on dry matter production characteristics of super hybrid rice. - Rice Sci. 15: 110-118, 2008.

(C) The authors. This is an open access article distributed under the terms of the Creative Commons BY-NC-ND Licence. 